Siti Novy Romlah et al_ Human Immunodeficiency Virus (Hiv) Pada Bayi Baru Lahir Ditinjau Dari Berbagai Literatur

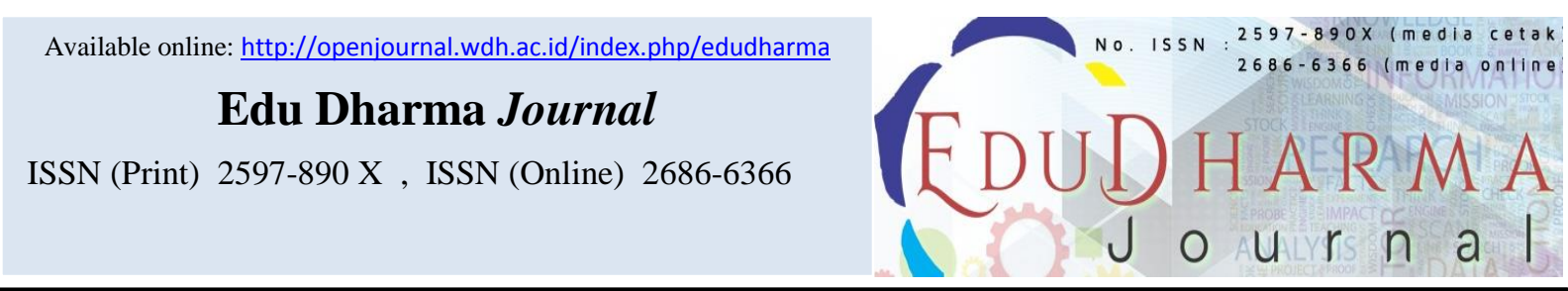

\title{
HUMAN IMMUNODEFICIENCY VIRUS (HIV) PADA BAYI BARU LAHIR DITINJAU DARI BERBAGAI LITERATUR
}

\author{
Siti Novy Romlah ${ }^{1 *}$, Ratumas Ratih Puspita ${ }^{2}$, Indri Yastiwi Fitri Hasanah ${ }^{3}$ \\ ${ }^{1,3}$ Program Studi D III Kebidanan STIKes Widya Dharma Husada Tangerang \\ ${ }^{2}$ Program Studi S1 Keperawatan STIKes Widya Dharma Husada Tangerang
}

\begin{tabular}{|c|c|}
\hline ARTICLE INFORMATION & $A \quad B \quad S \quad T \quad R A C T$ \\
\hline $\begin{array}{l}\text { *Corresponding Author } \\
\text { Siti Novy Romlah } \\
\text { E-mail : sitinovyromlah@wdh.ac.id }\end{array}$ & $\begin{array}{l}\text { Background. According to the report of the Ministry of Health of } \\
\text { the Republic of Indonesia (2013), from } 1 \text { January } 2013 \text { to } \\
\text { September } 2013 \text { HIV incidence reached } 20,413 \text { people. The } \\
\text { highest incidence of HIV occurs in the age group of } 25-49 \text { years } \\
\text { with a percentage of } 73.4 \% \text {. Risk sexual behavior in }\end{array}$ \\
\hline $\begin{array}{l}\text { Keywords: } \\
\text { HIV_1 } \\
\text { New Born_2 }\end{array}$ & $\begin{array}{l}\text { and } 78.4 \% \text { for AIDS. Research Objectives To find out HIV } \\
\text { disease in newborns. Research methods. This study uses the } \\
\text { literature method by taking from various sources of books and } \\
\text { journals. Research result. HIV from the mother to the fetus she } \\
\text { conceives starts during pregnancy, and can also be transmitted } \\
\text { during labor. Suggestion. It is hoped that health workers can } \\
\text { prevent HIV transmission to pregnant women to their babies. }\end{array}$ \\
\hline \multirow[t]{3}{*}{$\begin{array}{l}\text { Kata Kunci: } \\
\text { HIV_1 } \\
\text { Bayi Baru Lahir_2 }\end{array}$} & $\begin{array}{l}\text { A B S T R A K } \\
\text { Latar Belakang. Laporan Kemenkes RI (2013), pada } 1 \text { Januari } \\
2013 \text { sampai September } 2013 \text { HIV terjadi mencapai } 20.413 \\
\text { orang. HIV tertinggi terjadi pada kelompok usia } 25-49 \text { tahun } \\
\text { yaitu sebesar } 73,4 \% \text {. Faktor resiko tertinggi yaitu perilaku } \\
\text { seksual berisiko pada heteroseksual yaitu sebesar } 45,6 \% \text { untuk } \\
\text { HIV dan 78,4\% untuk AIDS. Tujuan Penelitian ini yaitu untuk } \\
\text { mengetahui penyakit HIV pada bayi baru lahir. Metode } \\
\text { Penelitian yang digunakan yaitu metode literatur dengan } \\
\text { mengambil dari berbagai sumber buku, dan jurnal. Hasil } \\
\text { Penelitian. HIV dari ibu ke janin yang dikandungnya dimulai } \\
\text { saat kehamilan, dan dapat juga tertular saat persalinan. Saran. } \\
\text { Dihararapkan tenaga kesehatan dapat mencegah penularan HIV } \\
\text { pada ibu hamil ke bayinya. }\end{array}$ \\
\hline & This is an open access article under the CC-BY-NC-SA license. \\
\hline & (C) 2020 Some rights reserved \\
\hline
\end{tabular}




\section{PENDAHULUAN}

Data dari United National Joint Programme for HIV and AIDS (2013) menyatakan bahwa pada tahun 2012 sekitar 35,3 juta orang di dunia hidup dengan HIV/ AIDS. Pada tahun yang sama jumlah kasus baru HIV di dunia mencapai 2,3 juta kasus dan kasus kematian karena AIDS mencapai 1,6 juta kasus. Menurut laporan Kemenkes RI (2013), sejak 1 Januari 2013 sampai dengan September 2013 kejadian HIV mencapai 20.413 orang. Kejadian tertinggi HIV terjadi pada kelompok usia 25-49 tahun dengan persentase $73,4 \%$. Perilaku seksual berisiko pada heteroseksual menjadi faktor risiko tertinggi. yaitu sebesar $45,6 \%$ untuk HIV dan $78,4 \%$ untuk AIDS. Perbandingan jumlah penderita laki-laki dan perempuan adalah 1:1 untuk HIV dan 2:1 untuk AIDS.

Jumlah penderita HIV / AIDS perempuan semakin bertambah seiring dengan meningkatnya penularan pada perilaku seksual tidak aman pada laki-laki yang kemudian menularkan HIV kepada pasangan seksualnya. Selain itu, penularan HIV dari ibu yang terinfeksi HIV kepada bayinya cenderung meningkat seiring dengan meningkatnya jumlah perempuan yang terinfeksi HIV. Pada triwulan III tahun 2013 yang menunjukkan faktor risiko penularan HIV dari ibu ke anak sebesar 4,3\%, meningkat 0,2\%. dari laporan Kemenkes tentang HIV triwulan II Tahun 2013. Penularan HIV dari ibu ke anak dapat tersebut dapat terjadi pada saat kehamilan, persalinan, dan menyusui.

Kementerian Kesehatan telah mengupayakan pencegahan penularan HIV/AIDS dari ibu ke anak sesuai rekomendasi WHO (2009) dengan menerbitkan Pedoman Pencegahan Penularan HIV dari Ibu ke Anak tahun 2012. PPIA merupakan salah satu upaya untuk mengendalikan HIV/AIDS dan Infeksi Menular Seksual (IMS) di Indonesia dan merupakan bagian dari program Kesehatan Ibu dan Anak (KIA). Program PPIA bertujuan untuk mengendalikan penularan HIV/AIDS, menurunkan kasus HIV serendah mungkin, mengurangi stigma dan diskriminasi, serta menurunkan kematian akibat AIDS (Getting to Zero). Program ini dapat dilaksanakan secara terintegrasi di setiap tingkatan layanan kesehatan dan dapat dilaksanakan oleh puskesmas dan jajarannya, rumah sakit, dan bidan praktik mandiri. Bidan dalam hal ini mempunyai peran yang sangat penting, dimana bidan berada di barisan terdepan dalam pelayanan kesehatan ibu dan anak. Meningkatnya penularan HIV dari ibu ke anak menyebabkan program PPIA harus 
segera dilaksanakan. Sesuai Pemodelan Matematik oleh Kementerian Kesehatan (2012), prevalensi HIV pada ibu hamil diproyeksikan akan meningkat dari $0,38 \%$ pada tahun 2012 menjadi $0,49 \%$ pada tahun 2016. Jumlah ibu hamil dengan HIV positif yang membutuhkan layanan PPIA akan meningkat dari 13.189 orang pada tahun 2012 menjadi 16.191 orang pada tahun 2016. Sejak Januari hingga September 2013, jumlah layanan PPIA yang dilaporkan di Indonesia adalah

Penelitian ini menggunakan metode Studi Literatur atau Studi Pustaka yang berhubungan dengan HIV Pada Bayi Baru Lahir Di Tinjau Dari Berbagai Literatur. Ruang lingkup penelitian ini dibatasi pada perkembangan HIV/AIDS, dimana didalamnya dijelskan tentang pengertian

\section{HASIL DAN PEMBAHASAN}

Human Immunodeficiency Virus (HIV) adalah retrovirus yang ditularkan secara seksual (melalui hubungan seksual tanpa pelindung), secara parenteral (melalui perlengkapan injeksi yang digunakan bersama-sama atau melalui tranfusi darah/penerima organ donor), atau dari ibu ke bayinya melalui penularan vertikal (selama kehamilan, persalinan, atau menyusui). HIV menginfeksi limfosit-T CD4 (komponen esensial dalam sistem sebanyak 114 pelayanan dan telah melayani 4364 ibu hamil.

Jumlah AIDS yang dilaporkan menurut Provinsi tahun 2009-2017 mengalami penurunan dari 349 orang ditahun 2009 menurun menjadi 2 orang pada tahun 2017. Menurut data di RSU Tangerang dari 494 orang yang melakukan test HIV terdapat 10 orang yang terkena HIV+ . (Kemenkes RI, 2017).

\section{METODE}

HIV/AIDS, pencegahan HIV/AIDS, penanganan HIV/AIDS, patogenesis, faktor risiko, pemeriksaan infeksi HIV, upaya preventif, pengobatan infeksi virus HIV, transmisi dan cara penularan ditinjau dari berbagai literatur.

\section{Pengertian HIV}

imun) membuatnya tidak efektif dalam melawan infeksi, dan memicu perburukan fungsi imun secara bertahap. Tubuh menjadi rentan terhadap berbagai infeksi, termasuk yang umum terjadi didalam tubuh yang biasanya dapat dikalahkan oleh sistem imun di kenal sebagai infeksi oportunistik (Elizabeth Haryanti. 2009). 


\section{Pengertian AIDS}

AIDS adalah penyakit yang berkembang saat individu tidak mampu melawan infeksi. AIDS disebabkan oleh virus kecil (sejenis kuman), yaitu HIV. Individu dapat memiliki HIV dalam tubuhnya selama beberapa tahun sebelum menunjukan tanda penyakit. Akan tetapi, HIV pada akhirnya akan membuat individu tersebut kesulitan melawan infeksi. Individu tersebut pun mulai mengalami masalah kesehata

\section{Faktor Risiko Penularan HIV Pada}

\section{Bayi}

Tingginya angka penularan vertikal dari ibu ke janin sangat dipengaruhi oleh adanya faktor risiko pada ibu hamil yang terinfeksi HIV. Faktor risiko tersebut adalah beratnya infeksi HIV yang diderita ibu, adanya penyakit infeksi lain pada genitalia ibu, dan kebiasaan ibu. Beratnya keadaan infeksi HIV pada ibu merupakan faktor risiko utama terjadinya penularan perinatal. Berdasarkan hasil studi, ternyata angka penularan vertikal lebih tinggi pada ibu terinfeksi HIV dengan gejala yang sangat berat dibanding ibu terinfeksi HIV tanpa gejala. Beratnya keadaan penyakit ibu ditentukan dengan menggunakan kriteria klinis dan jumlah partikel virus

Penularan dari ibu ke bayi menjadi penyebab sebagian besar infeksi HIV pada anak-anak. Transmisi transplasental dapat individu pengidap HIV semakin sulit diobati, individu tersebut menderita AIDS (Klein, dkk 2012). AIDS merupakan penyakit yang tergolong dalam penyakit defisiensi imun sekunder, yang untuk pertama kalinya dikenal tahun 1980 di Amerika Serikat. Sejak peristiwa itu jumlah penderita terus meningkat dan melanda di seluruh negara sebagai wabah yang menakutkan (Prof. Subowo, 2010).

yang terdapat dalam plasma serta keadaan imunitas ibu (Setiawan, 2009).

Menurut Kementerian Kesehatan RI dalam Pedoman Nasional Pencegahan Penularan HIV dari Ibu ke Anak (2012), ada tiga faktor utama yang berpengaruh pada penularan HIV dari ibu ke anak, yaitu faktor ibu, bayi/anak, dan tindakan obstetrik. Namun, yang berpengaruh terhadap penularan HIV selama masa kehamilan adalah faktor ibu, yang terdiri dari:
a. Jumlah virus (viral load)
b. Jumlah sel CD4
c. Status gizi selama hamil
d. Penyakit infeksi selama hamil

\section{Penularan HIV dari Ibu ke Bayi}

terjadi dini, dan virus telah diidentifikasi pada kehamilan yang diakhiri dengan abortus elektif. Namun, pada sebagian 
besar kasus, penularan terjadi pada periode peripartum, dan $15-40 \%$ bayi lahir dari ibu yang terinfeksi HIV dan tidak diobati akan terinfeksi. Komplikasi kehamilan,

Pencegahan Penularan HIV/AIDS dari Ibu ke Anak (PPIA) merupakan program pencegahan penularan HIV/AIDS dari ibu ke bayi. Konsep dasarnya adalah menurunkan Viral Load serendahrendahnya. Meminimalkan papaan janin/bayi dari cairan tubuh HIV positif. Lalu mengoptimalkan kesehatan bayi dari ibu dengan HIV positif (Khoriyah Isni, 2016)

Menurut Wudineh (2016) menyatakan pencegahan penularan HIV dari ibu ke anak merupakan program yang semakin menjadi perhatian seiring meningkatnya kejadian HIV pada ibu dan anak. Dengan intervensi yang baik maka risiko penularan HIV dari ibu ke bayi sebesar 25\% hingga $45 \%$ bisa ditekan menjadi kurang dari $2 \%$. Pelaksanaan PPIA pada pelayanan ibu dan anak dapat menurunkan angka kematian

Sampai saat ini, pengobatan yang tepat untuk menghindari atau menyembuhkan HIV atau AIDS tidak dijumpai atau masih dalam percobaan. Obat yang masih dalam percobaan adalah Azidothymidine (AZT) yang kerjanya untuk menghambat mencakup persalinan preterm, hambatan pertumbuhan janin, dan lahir mati, dikaitkan dengan infeksi HIV pada ibu.

\section{Pencegahan Penularan HIV Ibu}

Hamil ke Janin yang Dikandungnya pada ibu HIV. Pelayanan Bidan Praktik Mandiri merupakan salah satu fasilitas pelayanan kesehatan ibu dan anak yang ada di Indonesia. Bidan Praktik Mandiri merupakan tempat pelayanan dasar yang menjadi lini pertama deteksi dini terhadap komplikasi pada kehamilan termasuk HIV. Penelitian Ariningtyas (2017) menyatakan bahwa pelaksanaan PPIA pada pelayanan kesehatan ibu dan anak dapat menurunkan angka kematian pada ibu HIV. Pelayanan Bidan Praktik Mandiri merupakan salah satu fasilitas pelayanan kesehatan ibu dan anak yang ada di Indonesia. Program PPIA sebagai program pencegahan HIV dari ibu ke anak sebagian besar dapat dilakukan oleh bidan. Bidan dapat memberikan konseling dan dukungan pada perempuan yang tidak terinfeksi HIV maupun yang sudah terinfeksi HIV.

\section{Pengobatan Infeksi Virus HIV}

duplikasi virus intraseluler. Hasilnya masih belum dapat dipastikan untuk penyembuhan dan pengobatan massal. Selain itu, belum didapatkan data yang akurat tentang bagaimana pengaruh AZT terhadap penularan virus HIV ke janin. 
Di Indonesia, infeksi virus HIV telah banyak berjangkit, terutama akibat hubungan seksual yang makin bebas dan enggan mempergunakan kondom untuk preventifnya. Daerah-daerah potensial untuk infeksi virus HIV adalah kota besar yang tidak mungkin hidup tanpa tersedianya call girl. Kini, Indonesia telah

Penularan infeksi HIV dari ibu ke bayi merupakan penyebab utama infeksi HIV pada bayi usia di bawah 15 tahun. Sejak pertama kali dilaporkan oleh Oleske, Rubinstein dan Amman pada tahun 1983 di Amerika Serikat, terus terjadi peningkatan. Seiring dengan meningkatnya jumlah kasus HIV-AIDS pada perempuan yang diperkirakan $50 \%$ dari kasus HIV/AIDS (Judarwanto, 2009).

Pada tahun 2009, sebanyak 370.000 anakanak terinfeksi baru HIV di seluruh dunia dan diperkirakan 42.000-60.000 wanita hamil meninggal karena HIV. Kasus HIV pada bayi yang lahir dari ibu pengidap HIV merupakan masalah besar di negara-

Kasus pertama bayi tertular HIV dilaporkan pada tahun 1996 di Jakarta. Penularan HIV dari ibu ke bayi sat ini bertambah terus seiring meningkatnya petempuan yan ternfeksi HIV. Laporan triwulan Direktorat Jendral masuk tahap ke lima infeksi virus HIV. Ibu rumah tangga telah terinfeksi akibat tertular virus yang dibawa oleh seuaminya yang melakukan seks bebas atau tertular dari pria yang bukan suaminya saat melakukan hubungan seks dengannya (Manuaba, 2009).

\section{HIV Dalam Kehamilan}

negara berkembang. Ada sekitar 2 juta anak pengidap HIV di Negara-negara berkembang dan diperkirakan setiap hari terjadi 1.800 infeksi baru pada anak umur kurang dari 15 tahun, sebaliknya di negara berpendapatan tinggi jumlah infeksi HIV baru di kalangan ibu dan anak yang meninggal karena HIV adalah hampir nol. Hal ini dikarenakan perempuan atau anakanak mereka di negara-negara berpenghasilan rendah dan menengah, terlalu sedikit menerima pencegahan HIV dan layanan pengobatan untuk melindungi diri dan hal ini masih merupakan masalah besar (WHO, 2011).

\section{HIV Pada Bayi}

Penanggulangan Penyakit Menular dan Penyehatan Lingkungan (PP dan PL) Kementerian Kesehatan Republik Indonesia (Kemenkes RI) bulan Juni 2011 menunjukan jumlah kasus AIDS dengan faktor risiko transmisi perinatal (dari ibu 
dengan HIV ke bayinya) sebanyak 742 kasus. (Kementerian Kesehatan, 2011). Angka ini menunjukan peningkatan dua kali lebih tinggi dibandingkan tiga tahun sebelumnya yang hanya 351 kasus. Kenaikan kasus HIV pada bay ini terjadi seiring dengan kenaikan kasus AIDS pada perempuan, yakni dari $20 \%$ pada tahun

\section{KESIMPULAN}

1. Human Immunodeficiency Virus (HIV) adalah retrovirus yang ditularkan secara seksual (melalui hubungan seksual tanpa pelindung), secara parenteral (melalui perlengkapan injeksi yang digunakan bersama-sama atau melalui tranfusi darah/penerima organ donor), atau dari ibu ke bayinya melalui penularan vertikal (selama kehamilan, persalinan, atau menyusui).

2. HIV pertama kali ditemukan, tetapi sampai saat ini obatnya belum ditemukan sehingga bila terinfeksi virus HIV berarti sudah menuju kematian. Obat yang tersedia sekadar untuk mempertahankan atau memperpanjang usia, bukan untuk membunuh virus HIV.

3. Perkembangan HIV/AIDS di Indonesia sudah sangat menghawatirkan karena dari tahun ke
2007, $25 \%$ pada tahun 2008, menjadi $27 \%$ pada tahun 2011. Meningkatnya proporsi kasus AIDS pada perempuan ini menunjukan epidemi AIDS di Indonesia makin meningkat dan dipastikan akan meningkat jumlah bayi terinfeksi HIV di masyarakat (Departemen Kesehatan, 2008).

tahun terus mengalami peningkatan. Tahun 2005 ditemukan kasus HIV sebanyak 859 kasus dan kasus AIDS sebanyak 2.639 kasus, namun laporan triwulan kedua pada tahun 2013 angka kejadian HIV meningkat menjadi 10.210 kasus dan AIDS sebanyak 780 kasus.

4. AIDS adalah penyakit yang berkembang saat individu tidak mampu melawan infeksi. AIDS disebabkan oleh virus kecil (sejenis kuman), yaitu HIV.

5. hIV-1 dan HIV-2 memiliki sekitar $50 \%$ homologi dalam nukleotidanya sedang HIV mempunyai sekitar $80 \%$ homologi. Awal infeksi biasanya terjadi dengan cara paparan cairan tubuh yang berasal dari orang yang terinfeksi HIV. Virus HIV ditemukan sebagai partikel virus yang bebas dan terdapat dalam sel yang terinfeksi, dalam semen, cairan vagina dan air susu ibu (ASI). 
6. Infeksi virus HIV intrauterin dapat menyebabkan gangguan pertumbuhan bayi sekita $75 \%$, terutama mikrosefalia sekitar 70\%. Keadaan abnormal lainnya adalah hipertelorisme okular serta bentuk kepala prominen seperti segiempat, pangkal hidung datar, dan filtrum prominen. Selain itu, kematian intrauterin disebabkan oleh beratnya kelainan kongienital yang terjadi.

7. Penularan HIV dari ibu ke anak pada umumnya terjadi pada saat persalinan dan pada saat menyusui. Risiko penularan HIV pada ibu yang tidak mendapatkan penanganan PPIA saat hamil diperkirakan sekitar $15-45 \%$. Risiko penularan 15 - $30 \%$ terjadi pada saat hamil dan bersalin, sedangkan peningkatan risiko transmisi HIV sebesar $10-20 \%$ pada masa nifas dan menyusui.

\section{DAFTAR PUSTAKA}

Chris W Green. 2005. HIV Kehamilan dan Kesehatan Perempuan. Retrieved from http://i-base.info/wpcontent/uploads/2006/09/indonesianpregnancy.pdf

Ditjen PP \& PL Kemenkes RI. 2017. Laporan Situasi Perkembangan HIVAIDS \& PIMS Di Indonesia Triwulan I Tahun 2017. Kuningan: Jakarta Selatan.

Elizabeth Haryanti. 2009. Pencegahan Penularan Hiv Dari Ibu Ke Bayi
8. Faktor risiko penularan HIV dari ibu ke anak diantaranya, jumlah virus selama hamil, status imunitas ibu hamil, riwayat infeksi pada genetalia ibu, gaya hidup dan faktor perilaku, faktor obstetri seperti cara melahirkan bayi dan proses persalinan bayi, dan pemberian ASI kepada bayi sesudah lahir.

9. Pencegahan Penularan HIV/AIDS dari Ibu ke Anak (PPIA) merupakan program pencegahan penularan HIV/AIDS dari ibu ke bayi. Konsep dasarnya adalah menurunkan Viral Load serendah-rendahnya. Meminimalkan papaan janin/bayi dari cairan tubuh HIV positif. Lalu mengoptimalkan kesehatan bayi dari ibu dengan HIV positif.

(Prevention Of Mother To Child Hiv Transmission/Pmtct), 85-108. Retrieved from http://journal.wima.ac.id/index.php

Evalina, R., 2012. Studi Deskritif Infeksi HIV pada Anak di Rumah Sakit Umum Pusat Adam Malik Medan. Sari Pediatri, 14(2): 73-78.

Kementerian Kesehatan 2011. Pedoman Nasional Tatalaksana Klinis Infeksi HIV dan Terapi Antiretroviral. Jakarta. Kementerian Kesehatan.

Kementerian Kesehatan 2012. Pedoman Nasional Pencegahan Penularan HIV 
Siti Novy Romlah et al_ Human Immunodeficiency Virus (Hiv) Pada Bayi Baru Lahir Ditinjau Dari Berbagai Literatur

dari Ibu ke Anak. Jakarta. Kementerian Kesehatan.

Kemenkes RI. 2014. Pedoman Pelaksanaan Pencegahan Penularan HIV Dan Sifilis Dari Ibu Ke Anak Bagi Tenaga Kesehatan. Jakarta. Kementerian Kesehatan

Kementerian kesehatan.2015. Pedoman Manajemen Program Pencegahan Penularan HIV dan Sifilis Dari Ibu ke Anak. Jakarta.

Kemenkes RI. 2019. Pedoman Nasional Pelayanan Kedokteran Tata Laksana HIV. Jakarta. Kementrian Kesehatan Republik Indonesi

Kumalasari, Mei Liana Fitri. 2014. Hubungan Antara Pengetahuan Ibu Hamil Tentang HIV/AIDS Dengan Motivasi Mengikuti PMTCT (Prevention-Mother-To-Child-

Transmission) Di RSUD Dr. Moewardi Surakarta, 23-26. Retrieved from http://jurnal.stikeskusumahusada.ac.id /index.php/JK/article/download/80/12 3

Khoiriyah Isni. 2016. Dukungan Keluarga, Dukungan Petugas Kesehatan, Dan Perilaku Ibu Hiv Dalam Pencegahan Penularan Hiv/Aids Ke Bayi, 11(2).

Manuaba. 2009. Memahami Kesehatan reproduksi wanita, Jakarta : EGC

Manuaba. 2010. Ilmu kebidanan, penyakit kandungan, dan KB. Jakarta: Buku Kedokteran EGC.

Ningsih, Hastuti. 2018. Kajian Pencegahan Penularan HIV Dari Ibu Ke Anak Pada Antenatal Care Oleh Bidan Praktik Mandiri di Yogyakarta. Yogyakarta
Ningsih, I. K. 2018. Kajian Pencegahan Penularan Hiv Dari Ibu Ke Anak Pada Antenatal Care Oleh Bidan Praktik Mandiri Di Yogyakarta, 6, 61-67. Retrieved from https://ejournal.unair.ac.id/JAKI/article/down $\underline{\text { load/6117/5002 }}$

Rita Evalina. 2012. Studi Deskriptif Infeksi HIV Pada Anak Di Rumah Sakit Umum Pusat Adam Malik Medan, 14(2), 73-78. Retrieved from https://www.researchgate.net/publicat ion/312175563_Studi_Deskriptif_Inf eksi_HIV_pada_Anak_di_Rumah_Sa kit_Umum_Pusat_Adam_Malik_Med an/fulltext/59edf442a6fdccbbefd542b 8/312175563_Studi_Deskriptif_Infek si_HIV_pada_Anak_di_Rumah_Sakit _Umum_Pusat_Adam_Malik_Medan .pdf?origin=publication detail

Suradi, R. 2003. Tata Laksana Bayi dari Ibu pengidap HIV/AIDS, 4(6), 180185. Retrieved from https://www.researchgate.net/publicat ion/312199542_Tata_laksana_Bayi_d ari_Ibu_pengidap_HIVAIDS/fulltext/ 59edef14a6fdccbbefd2714d/3121995 42_Tata_laksana_Bayi_dari_Ibu_pen gidap_HIVAIDS.pdf?origin=publicat ion_detail 